\title{
Comparison of Plasma Cell Type of Castleman's Disease and IgG4-Related Sclerosing Disease: A Histopathological and Immunohistochemical Study
}

\author{
Jeong-Hyeon Jo ${ }^{a}$ Young-Soo Park ${ }^{a}$ Yoon Kyung Jeon ${ }^{b}$ Soo Jeong Nam ${ }^{b}$ \\ Jooryung Huh ${ }^{\mathrm{a}}$ \\ a Department of Pathology, University of Ulsan College of Medicine, Asan Medical Center, and \\ ${ }^{b}$ Department of Pathology, Seoul National University College of Medicine, Seoul, South Korea
}

\section{Key Words}

Castleman's disease $\cdot \lg$ G4-related sclerosing disease $\cdot$

Plasma cell $\cdot$ Immunohistochemistry

\begin{abstract}
Objectives: Castleman's disease (CD) is a group of rare atypical lymphoproliferative disorders classified as hyaline vascular (HV) and plasma cell (PC) types. CD may be closely mimicked by lgG4-related sclerosing disease (IgG4-SD) involving the lymph nodes. We retrospectively analyzed findings in patients with $C D$ to elucidate the relationship between $C D$ and IgG4-SD. Methods: Clinicopathological and immunophenotypical characteristics, including IgG+ and IgG4 expression by plasma cells, were analyzed in 87 consecutive patients diagnosed with CD from 1999 to 2010 at two major Korean hospitals. Results: The numbers of IgG+ $(p<0.001)$ and IgG4+ $(p<0.001)$ cells and the IgG4:IgG ratio $(p=0.003)$ were significantly higher in the PC than in the HV group. The mean IgG4+:IgG+ plasma cell ratio in the PC group was $25.1 \%$, with 10 patients having a ratio $>40 \%$, the threshold IgG4:IgG ratio in patients with IgG4-SD. Conclusions: $\mathrm{Pa}-$ tients with the $P C$ form of $C D$ and IgG4-related lymphade-
\end{abstract}

nopathy share some features, including the pattern of plasma cell distribution and high-level infiltration of lgG4+ cells. Some patients thought to have the PC form of CD could be reclassified as showing IgG4-related lymphadenopathy.

Copyright $\odot 2011$ S. Karger AG, Basel

\section{Objectives}

Since Kamisawa et al. [1] proposed the concept of IgG4-related sclerosing disease (IgG4-SD) to explain that autoimmune pancreatitis is a pancreatic manifestation of a systemic disease, various organs have been reported to be involved: lung, breast, central nervous system, liver and intestine [2-6]. Some idiopathic fibrosing diseases such as retroperitoneal fibrosis $[7,8]$ and sclerosing mediastinitis [9] can be explained by this concept. When IgG4-SD involves multiple lymph nodes presenting as systemic lymphadenopathy, it can show some overlapping features with multicentric Castleman's disease (CD) [10] such as hyalinized blood vessels, increased high endothelial venules, and many plasma cells in the interfollicular region [11].

\section{KARGER}

Fax +41613061234 E-Mail karger@karger.ch www.karger.com
(C) 2011 S. Karger AG, Basel

1015-2008/11/0784-0227\$38.00/0

Accessible online at:

www.karger.com/pat
Jooryung Huh, Department of Pathology

Asan Medical Center, University of Ulsan College of Medicine

388-1 Poongnap-Dong, Songpa-Ku

Seoul 138-736 (South Korea)

Tel. +82 23010 4553, E-Mail jrhuh@ amc.seoul.kr 
Table 1. Clinical characteristics of patients with CD

\begin{tabular}{ll}
\hline Factor & $\mathrm{n}$ \\
\hline $\begin{array}{l}\text { Age, years } \\
\text { Gender }\end{array}$ & $11-87$ (mean 41.9$)$ \\
$\quad$ Male & $54(62.1 \%)$ \\
$\quad$ Female & $33(37.9 \%)$ \\
Site & $35(40.2 \%)$ \\
$\quad$ Neck & $12(13.8 \%)$ \\
Abdominal cavity & $5(5.7 \%)$ \\
Mediastinum & $6(6.9 \%)$ \\
$\quad$ Retroperitoneum & $8(9.0 \%)$ \\
$\quad$ Specific organ (lung, kidney, etc.) & $21(24.1 \%)$ \\
LN other than neck & $1.1-15.0($ median 3.2$)$ \\
Size of LN, cm & \\
Multicentricity & $57(65.5 \%)$ \\
Single & $30(34.5 \%)$ \\
$\quad$ Multiple & \\
\hline
\end{tabular}

LN = Lymph node.

In this study, we evaluated the numbers and the distribution pattern of IgG-positive (IgG+) and IgG4-positive (IgG4+) plasma cells in CD to find relationship between CD and IgG4-SD.

\section{Patients and Methods}

Data from 87 patients with CD, including 55 consecutive patients diagnosed at the Asan Medical Center, Seoul, Korea, from 1999 to 2010, and 32 consecutive patients diagnosed at Seoul National University from 2001 to 2010, were analyzed in the study. The medical records of each patient were reviewed and clinical histories as well as follow-up data were recorded, including patient age, gender, original tumor site, tumor size and evidence of human immunodeficiency virus (HIV) infection. The multicentricity was assessed using the results of computed tomography; it was defined as a multicentric case when enlarged lymph nodes were identified in at least three different sites. Laboratory tests evaluated the presence in serum of human herpes virus 8 (HHV8) and serum concentrations of IgG and IgG4 if available. The histological features of each patient were used to reclassify patients into two groups, a hyaline vascular (HV) and a plasma cell (PC) group. Patients in the PC group showed at least one region with sheets of plasma cells and mixed cell types.

To preserve nodal structures, we made multispecimen blocks [12] from formalin-fixed paraffin-embedded tissue sections and incubated these blocks with antibodies to IgG (1:200; Dako, Glostrup, Denmark) and IgG4 (1:2,000; Binding Site, Birmingham, UK). Immunohistochemical staining results were evaluated by determining the distribution patterns of IgG+ plasma cells, the numbers of IgG+ and IgG4+ plasma cells, and the ratio of IgG4+ to IgG+ plasma cells. The distribution patterns of IgG+ plasma cells were classified into a diffuse type, if at least one high-power field (HPF) was filled with IgG+ plasma cells, and a focal type, if IgG+ plasma cells were present, but not to the extent seen in the diffuse type. If no IgG+ cells were evident, the sample was classified as negative. The numbers of IgG+ and IgG4+ cells were counted using the UTHSCSA Image Tool (University of Texas Health Science Center, San Antonio, Tex., USA). The average numbers of IgG+ and IgG4+ cells per HPF were evaluated by enumeration of three areas showing the highest densities of positive cells. Samples were also immunostained with antibodies to $\kappa$ (1:100; Dako) and $\lambda$ (1:4,000; Dako) light chains to exclude the possibility of malignant lymphoma. Epstein-Barr virus (EBV) status was assessed by in situ hybridization for EBV-encoded RNA, and the samples were also immunostained with antibody to HHV8 (1:20; Cell Marque, Rocklin, Calif., USA).

The $\chi^{2}$ test was used to assess the relationships among multicentricity, distribution patterns of IgG+ cells and the new subgroups of CD. Student's t test was employed to compare the numbers of IgG+ and IgG4+ cells per HPF and the ratio of IgG4+ to $\mathrm{IgG}+$ cells in subgroups. All statistical analyses were performed using SPSS version 12.0 (SPSS Inc., Chicago, Ill., USA).

\section{Results}

The 87 patients consisted of 54 males and 33 females, with a median age of 41.9 years (range: $11-87$ years). The most common site of involvement was the neck lymph nodes (35 patients, $40.2 \%$ ), followed by nodes of the abdominal cavity (12 patients, 13.8\%). Involved lymph nodes were highly variable in size, ranging from 1.0 to $15.0 \mathrm{~cm}$ in the greatest dimension (mean $4.3 \mathrm{~cm}$ ). Thirty patients $(34.5 \%)$ showed multicentricity, including a patient with involvement of whole body lymph nodes and the bone marrow. Table 1 summarizes the clinicopathological characteristics of patients with CD.

Of the 87 patients, 51 were diagnosed with HV type, 24 with PC type and 12 with mixed-type disease. Patients with the HV type of disease showed classic node morphology, with thick hyalinized vessels and either absence of IgG+ or IgG4+ cells, or focal presence of such cells in interfollicular areas. In contrast, distinctive thick vessels were absent in patients with the PC type of disease, and interfollicular areas were expanded with sheets of plasma cells. Immunohistochemical staining showed that such plasma cells were diffusely positive for IgG and a significant portion of them was also positive for IgG4. In mixedtype patients, the characteristic vessels were less prominent, but features of both the HV and PC types were seen (fig. 1). Obliterating phlebitis was not identified in any patient.

Based on the presence of plasma cells, we reclassified the patients into two groups, an HV group (51 patients, 

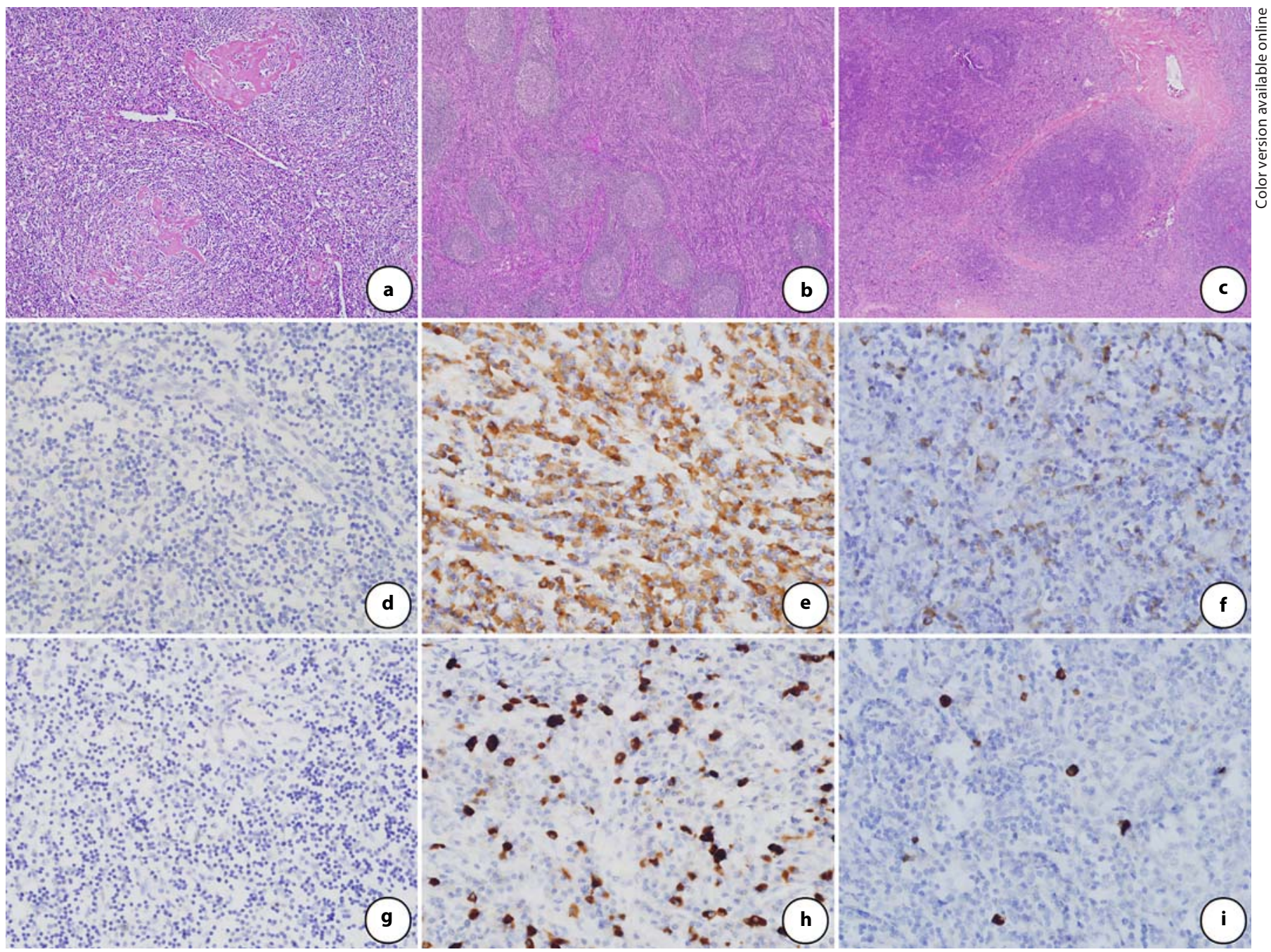

Fig. 1. Microscopic findings of three types of CD, as shown by immunohistochemical staining for IgG and IgG4. The hyaline vascular type (a) shows a typical hyalinized vascular pattern without IgG+ (d) or IgG4+ (g) cells. Interfollicular areas of the plasma cell type (b) are expanded with sheets of plasma cells positive for IgG (e), with some plasma cells also positive for IgG4 (h). The mixed type (c) shows regions of both the hyaline vascular and plasma cell types, with some IgG+ (f) and IgG4+ (i) cells.

Table 2. Multicentricity and the pattern of IgG+ cells in subgroups of patients with CD

\begin{tabular}{lccc}
\hline Factor & \multicolumn{2}{l}{ Number of patients } & \multirow{2}{*}{$\mathrm{p}$} \\
\cline { 2 - 3 } & HV group & PC group & \\
\hline Multicentricity & $11 / 51(21.6)$ & $19 / 36(52.8)$ & 0.011 \\
Pattern of IgG+ cells & & & \\
$\quad$ Diffuse & $12 / 51(23.5)$ & $27 / 36(75.0)$ & $<0.001$ \\
$\quad$ Focal & $28 / 51(54.9)$ & $9 / 368(25.0)$ & \\
$\quad$ Negative & $11 / 51(21.6)$ & $0 / 36(0.0)$ & \\
\hline
\end{tabular}

Figures in parentheses are percentages.
Table 3. IgG+ and IgG4+ cells in subgroups of patients with CD

\begin{tabular}{lccr}
\hline \multirow{2}{*}{ Factor } & \multicolumn{2}{c}{ Mean } & \multirow{2}{*}{$\mathrm{p}$} \\
\cline { 2 - 3 } & HV group & PC group & \\
\hline IgG+ cells/HPF & 73.3 & 214.5 & $<0.001$ \\
IgG4+ cells/HPF & 13.3 & 54.6 & $<0.001$ \\
IgG4+ cells/IgG+ cells & 9.9 & 25.3 & 0.002 \\
\hline
\end{tabular}

Comparison of CD and IgG4-Related 
Table 4. Clinicopathological characteristics of the cases with high IgG4/IgG ratio (>40\%)

\begin{tabular}{|c|c|c|c|c|c|c|c|c|c|c|c|c|c|}
\hline Case & $\begin{array}{l}\text { Age } \\
\text { years }\end{array}$ & Sex & Site & Multicentricity & Dx & HHV8 & $\begin{array}{l}\text { IgG } \\
\text { pattern }\end{array}$ & $\begin{array}{l}\text { IgG/ } \\
\text { HPF }\end{array}$ & $\begin{array}{l}\text { IgG4/ } \\
\text { HPF }\end{array}$ & $\begin{array}{l}\text { IgG4/ } \\
\text { IgG, \% }\end{array}$ & $\begin{array}{l}\text { Serum IgG4 } \\
\mathrm{mg} / \mathrm{dl}\end{array}$ & $\begin{array}{l}\text { Serum IgG } \\
\mathrm{mg} / \mathrm{dl}\end{array}$ & $\begin{array}{l}\mathrm{CRP} \\
\mathrm{mg} / \mathrm{dl}\end{array}$ \\
\hline 22 & 24 & female & neck & single mass & $\mathrm{HV}$ & negative & diffuse & 136 & 98 & 72.1 & - & - & 0.05 \\
\hline 42 & 34 & male & mediastinum & single mass & $\mathrm{HV}$ & negative & diffuse & 176 & 69 & 39.2 & - & - & - \\
\hline 44 & 34 & male & neck & single mass & $\mathrm{HV}$ & negative & diffuse & 120 & 48 & 40.0 & - & - & - \\
\hline 75 & 38 & male & abdominal cavity & single mass & $\mathrm{HV}$ & negative & focal & 69 & 37 & 53.6 & - & - & - \\
\hline 84 & 57 & male & neck & single mass & $\mathrm{HV}$ & negative & diffuse & 194 & 101 & 52.1 & - & - & - \\
\hline 9 & 52 & female & kidney & single mass & PC & negative & diffuse & 249 & 236 & 94.8 & - & - & - \\
\hline 31 & 15 & female & neck & multicentric & PC & negative & diffuse & 237 & 142 & 59.9 & - & - & 0.44 \\
\hline 45 & 29 & male & inguinal LN & single mass & $\mathrm{PC}$ & negative & diffuse & 280 & 162 & 57.9 & 0.84 & 1,490 & - \\
\hline 51 & 38 & male & inguinal LN & multicentric & PC & negative & diffuse & 230 & 134 & 58.3 & - & - & 10.11 \\
\hline 53 & 49 & male & neck & multicentric & $\mathrm{PC}$ & NA & focal & 62 & 50 & 81.0 & 0.42 & 2,250 & - \\
\hline 71 & 54 & male & abdominal cavity & multicentric & PC & negative & focal & 43 & 18 & 41.9 & - & - & - \\
\hline 74 & 26 & male & mediastinum & multicentric & $\mathrm{PC}$ & negative & diffuse & 205 & 178 & 86.8 & - & - & - \\
\hline
\end{tabular}

Dx = Diagnosis; $\mathrm{LN}=$ lymph node.

Table 5. Clinicopathological characteristics of the cases with serum IgG level

\begin{tabular}{|c|c|c|c|c|c|c|c|c|c|c|c|c|c|}
\hline Case & $\begin{array}{l}\text { Age } \\
\text { years }\end{array}$ & Sex & Site & Multicentricity & Dx & HHV8 & $\begin{array}{l}\text { IgG } \\
\text { pattern }\end{array}$ & $\begin{array}{l}\text { IgG/ } \\
\text { HPF }\end{array}$ & $\begin{array}{l}\text { IgG4/ } \\
\text { HPF }\end{array}$ & $\begin{array}{l}\text { IgG4/ } \\
\text { IgG, \% }\end{array}$ & $\begin{array}{l}\text { Serum IgG4 } \\
\mathrm{mg} / \mathrm{dl}\end{array}$ & $\begin{array}{l}\text { Serum IgG } \\
\mathrm{mg} / \mathrm{dl}\end{array}$ & $\begin{array}{l}\text { CRP } \\
\mathrm{mg} / \mathrm{dl}\end{array}$ \\
\hline 11 & 13 & male & neck & multicentric & PC & negative & diffuse & 275 & 42 & 15.3 & - & 1,080 & 19.39 \\
\hline 27 & 47 & male & inguinal LN & multicentric & $\mathrm{PC}$ & negative & diffuse & 290 & 73 & 25.2 & - & 1,270 & 1.26 \\
\hline 32 & 38 & male & retroperitoneum & multicentric & $\mathrm{HV}$ & positive & diffuse & 290 & 20 & 6.9 & - & 1,920 & 6.84 \\
\hline 45 & 29 & male & inguinal LN & single mass & $\mathrm{PC}$ & negative & diffuse & 280 & 162 & 57.9 & 0.84 & 1,490 & - \\
\hline 53 & 49 & male & maxillary sinus & multicentric & $\mathrm{PC}$ & negative & focal & 62 & 50 & 80.6 & 0.42 & 2,250 & - \\
\hline 59 & 68 & male & neck & single mass & $\mathrm{HV}$ & negative & focal & 68 & 25 & 36.8 & - & 1,325 & - \\
\hline 60 & 51 & male & neck & single mass & PC & negative & focal & 130 & 15 & 14.6 & - & 1,399 & - \\
\hline 78 & 50 & male & inguinal LN & multicentric & PC & negative & diffuse & 232 & 21 & 9.1 & - & 3,087 & - \\
\hline
\end{tabular}

Dx = Diagnosis; $\mathrm{LN}=$ lymph node.

$58.6 \%$ ) and a PC group (36 patients, 41.4\%). The PC group included patients with at least one region showing sheets of plasma cells. Multicentricity was significantly more common in the $\mathrm{PC}(19 / 36$ patients, $52.8 \%)$ than in the HV $(11 / 51$ patients, $21.6 \%)$ group $(\mathrm{p}=0.003)$. The pattern of IgG+ plasma cells was focal or negative in most patients of the HV group (37/51, 72.6\%), whereas the pattern was diffuse in most of those in the PC group $(27 / 36,75.0 \%)$ (table 2).

The mean numbers of IgG+ cells/HPF (214.5 vs. 73.3, $\mathrm{p}<0.001)$ and IgG4+ cells/HPF (54.6 vs. $13.3, \mathrm{p}<0.001)$ were significantly higher in the PC than in the HV group. In addition, the mean ratio of IgG4+ to IgG+ cells was significantly greater in the $\mathrm{PC}$ than in the $\mathrm{HV}$ group (25.3 vs. $9.9 \%, p=0.002$ ) although the ratio in the PC group ranged from 0 to $94.8 \%$.
When we analyzed the patients with an IgG4 to IgG ratio $>40 \%$ [11], we found that patient age, tumor size, original site or multicentricity did not differ between the two groups. However, when we compared patients with multicentric and unicentric $\mathrm{CD}$, we found that the former patients were significantly older (mean age, 47.3 vs. 39.1 years, $\mathrm{p}=0.050$ ) and had a higher mean serum IgG concentration $(1,921$ vs. $1,404 \mathrm{mg} / \mathrm{dl}, \mathrm{p}=0.226)$. We also found that the mean numbers of IgG+ (152 vs. 121, p = 0.220 ) and IgG4+ (33 vs. $29, \mathrm{p}=0.659)$ plasma cells per HPF, as well as the IgG4 to IgG ratio (19.7 vs. $14.5 \%$, p = 0.323 ), were slightly higher in the multicentric group. The clinicopathological characteristics of these patients are summarized in table 4.

Immunohistochemical staining showed that samples from 25 patients expressed $\kappa$ and $\lambda$ light chains, but none 
showed restrictions, indicating that none of these patients had malignant lymphoma. Five patients were positive for EBV by in situ hybridization, but there was no relationship between EBV status and diagnosis ( $p=$ 0.355). The serum of 5 patients was positive for HHV8, with 3 also being positive on immunohistochemical staining.

Serum concentrations of IgG and IgG4 were evaluated in 8 patients, and found to range from 1,080 to $3,087 \mathrm{mg} /$ dl. Of these 8 patients, 6 (75.0\%) belonged histologically to the PC group and $5(62.5 \%)$ were multicentric. The mean IgG4 to IgG ratio in these patients was $30.6 \%$. No patient showed other features suggesting IgG4-SD during the follow-up period. Table 5 shows the clinicopathological characteristics of these patients.

\section{Discussion}

$\mathrm{CD}$ is a group of rare atypical lymphoproliferative disorders, classified as HV, PC and mixed types [13]. The $\mathrm{HV}$ type is characterized by the presence of distinctive follicles with an expanded mantle zone and prominent vessels in the germinal centers associated with hyalinization, whereas the histological features of the PC type are less distinctive. In the lymph nodes, the PC type is characterized by variable germinal center hyperplasia with expanded mantle zones and a marked paracortical plasmacytosis $[14,15]$.

Because of this last feature (paracortical plasmacytosis), CD has been re-evaluated to consider IgG4+ cell infiltration $[11,16]$. The lymphadenopathy of IgG4-SD has been described as CD like, with follicular hyperplasia and an interfollicular expansion pattern [11]. Moreover, the lymphadenopathy of IgG4-SD with a CD-like pattern showed an intact nodal architecture with many reactive follicles and moderate-to-large numbers of mature plasma cells in the interfollicular zone. The number of IgG4+ plasma cells ranged from 17 to 877 per HPF (median 383), with 43-99\% (median, 58\%) of IgG+ cells in lymph nodes being IgG4+ cells. In patients with the CD-like pattern, the number of IgG4+ cells per HPF was rather high (mean 521 ), with a mean of $50 \%$ of IgG+ plasma cells being IgG4+.

We observed higher numbers of IgG4+ cells per HPF in the PC than in the HV group, with the ratio of IgG4+ to IgG+ cells being significantly higher in the PC group. Moreover, of the 35 patients in the PC group, 10 had sufficiently high IgG4+ to IgG+ ratios (41.9-94.8\%) to overlap with that seen in IgG4-SD patients [11].
The etiology of $\mathrm{CD}$ is probably heterogeneous, although IL-6, a pro-inflammatory cytokine, is involved in the pathogenesis of $\mathrm{CD}$, especially in systemic manifestations thereof [15]. Moreover, treatment of multicentric CD with anti-IL- 6 antibody has been shown to be effective [17], indicating that IL- 6 plays a role in CD. Elevated serum IL-6 may induce expansion of IgG4-SD to mimic CD [18], although systemic IgG4-related lymphadenopathy can be differentiated from multicentric $\mathrm{CD}$ by the older age of patients, and lower C-reactive protein and IL- 6 concentrations, in those with the former disease [10].

HHV8-positive rate in this study was low (5.7\%) and no patient showed HIV positivity. However, those data were similar to HHV8- and HIV-positive rates in Asian patients in a previous study [19].

As our study was retrospective in design, we have only limited information on included patients. Serum concentrations of IgG were measured in only 6 patients and IgG subclasses were evaluated in only 2 . The majority of patients were lost during the follow-up period after the biopsy or the excision of the lesions. However, serum IgG concentrations were very high $(1,920-3,087 \mathrm{mg} / \mathrm{dl})$ in 3 of the 6 patients, with 2 having high IgG4+ to IgG+ ratios (58 and 80\%). These findings provide further evidence for overlapping features in patients with the $\mathrm{PC}$ type of $\mathrm{CD}$ and those with IgG4-SD. Multicentric CD and lymphadenopathy in IgG4-SD are rather similar in histological features and the two conditions also share the distribution pattern of IgG+ plasma cells and high IgG4 concentration.

In conclusion, at least some patients with $\mathrm{CD}$ may be hard to differentiate from those with IgG4-related lymphadenopathy. Some patients with the PC type of CD should perhaps be reclassified as having IgG4-SD.

References

Pathobiology 2011;78:227-232
1 Kamisawa T, Nakajima H, Egawa N, Funata N, Tsuruta K, Okamoto A: IgG4-related sclerosing disease incorporating sclerosing pancreatitis, cholangitis, sialadenitis and retroperitoneal fibrosis with lymphadenopathy. Pancreatology 2006;6:132-137.

-2 Zen Y, Inoue D, Kitao A, Onodera M, Abo H, Miyayama S, Gabata T, Matsui O, Nakanuma Y: IgG4-related lung and pleural disease: a clinicopathologic study of 21 cases. Am J Surg Pathol 2009;33:1886-1893.

3 Chan SK, Cheuk W, Chan KT, Chan JK: IgG4-related sclerosing pachymeningitis: A previously unrecognized form of central nervous system involvement in IgG4-related sclerosing disease. Am J Surg Pathol 2009;33: 1249-1252. 
4 Cheuk W, Chan AC, Lam WL, Chow SM, Crowley P, Lloydd R, Campbell I, Thorburn M, Chan JK: IgG4-related sclerosing mastitis: description of a new member of the IgG4related sclerosing diseases. Am J Surg Pathol 2009;33:1058-1064.

5 Deshpande V, Sainani NI, Chung RT, Pratt DS, Mentha G, Rubbia-Brandt L, Lauwers GY: IgG4-associated cholangitis: a comparative histological and immunophenotypic study with primary sclerosing cholangitis on liver biopsy material. Mod Pathol 2009;22: 1287-1295.

6 Narula N, Vasudev M, Marshall JK: IgG(4)related sclerosing disease: a novel mimic of inflammatory bowel disease. Dig Dis Sci 2010;55:3047-3051.

$>7$ Gill J, Taylor G, Carpenter L, Lewis C, Chiu W: A case of hyperIgG4 disease or IgG4-related sclerosing disease presenting as retroperitoneal fibrosis, chronic sclerosing sialadenitis and mediastinal lymphadenopathy. Pathology 2009;41:297-300.

-8 Kojima M, Nakamura N, Motoori T, Shimizu K, Haratake J, Nakamura S: IgG4-related disorder of the retroperitoneum resembling Castleman's disease plasma cell type: a report of 2 cases. Int J Surg Pathol 2011;19:220224.
Inoue M, Nose N, Nishikawa H, Takahashi M, Zen Y, Kawaguchi M: Successful treatment of sclerosing mediastinitis with a high serum IgG4 level. Gen Thorac Cardiovasc Surg 2007;55:431-433.

10 Sato Y, Kojima M, Takata K, Morito T, Asaoku H, Takeuchi T, Mizobuchi K, Fujihara M, Kuraoka K, Nakai T, Ichimura K, Tanaka T, Tamura M, Nishikawa Y, Yoshino T: Systemic IgG4-related lymphadenopathy: a clinical and pathologic comparison to multicentric Castleman's disease. Mod Pathol 2009;22:589-599.

11 Cheuk W, Yuen HK, Chu SY, Chiu EK, Lam LK, Chan JK: Lymphadenopathy of IgG4-related sclerosing disease. Am J Surg Pathol 2008;32:671-681.

12 Petrosyan K, Press MF: Multispecimen tissue blocks in pathology: an improved technique of preparation. Lab Invest 1997;77: 541-542.

13 Naeim F, Rao P, Grody W: Hematopathology. San Diego, Academic Press, 2008.

14 Cronin DM, Warnke RA: Castleman disease: an update on classification and the spectrum of associated lesions. Adv Anat Pathol 2009; 16:236-246.

15 Dham A, Peterson BA: Castleman disease. Curr Opin Hematol 2007;14:354-359.
16 Ohta T, Furukawa Y, Aoyama Y, Kumura T, Mugitani A, Nakamae H, Koh K, Yamane T, Hino M: Multicentric Castleman diseaselike case characterized by lymphadenopathy and polyclonal hypergammaglobulinemia associated with so-called Mikulicz disease. Rinsho Ketsueki 2007;48:229-234.

17 Matsuyama M, Suzuki T, Tsuboi H, Ito S, Mamura M, Goto D, Matsumoto I, Tsutsumi A, Sumida T: Anti-interleukin-6 receptor antibody (tocilizumab) treatment of multicentric Castleman's disease. Intern Med 2007;46:771-774

18 Yamamoto M, Takahashi H, Hasebe K, Suzuki C, Naishiro Y, Hayashi T, Yamamoto H, Ishida T, Shinomura Y: The analysis of interleukin-6 in patients with systemic IgG4-related plasmacytic syndrome - expansion of sips to the territory of Castleman's disease. Rheumatology (Oxford) 2009;48:860-862.

-19 Nishimoto N, Kanakura Y, Aozasa K, Johkoh T, Nakamura M, Nakano S, Nakano N, Ikeda Y, Sasaki T, Nishioka K, Hara M, Taguchi H, Kimura Y, Kato Y, Asaoku H, Kumagai S, Kodama F, Nakahara H, Hagihara K, Yoshizaki K, Kishimoto T: Humanized anti-interleukin- 6 receptor antibody treatment of multicentric Castleman disease. Blood 2005; 106:2627-2632. 